\title{
Original
}

\section{Essential Role of Extracellular Type V Collagen for Porcine Adipocyte Development}

\author{
Ikuyo Nakajima $^{1}$, Fumio Nakamura ${ }^{2}$ and Koichi Chikuni ${ }^{1}$ \\ ${ }^{1}$ Institute of Livestock and Grassland Science, NARO, Tsukuba, Ibaraki 305-0901, Japan \\ ${ }^{2}$ Research Faculty of Agriculture, Hokkaido University, Sapporo, Hokkaido 060-8589, Japan
}

(Received : September 8, 2020, Accepted : December 16, 2020)

\begin{abstract}
The aim of this study was to examine the role of collagens in the differentiation of porcine subcutaneous preadipocytes (PSPA) using a specific post-transcriptional inhibitor of collagen synthesis, ethyl-3,4-dihydroxybenzoate (EDHB). Exponentially growing fibroblast-like PSPA cells were found to produce types I, III, IV, V and VI collagens by indirect immunofluorescence staining. When confluent preadipocyte cultures were stimulated with differentiation medium, various types of collagen matrices were assembled in the extracellular space of adipocytes. Since preadipocytes scarcely interconnect collagens despite the steady-state level expression of procollagen mRNAs, it appears that increasing the cell-associated form of collagens is an event unique to adipocytes. PSPA cells exposed to $40 \mu \mathrm{M}$ EDHB severely damaged the development of collagen fibrillar networks in adipocytes without affecting their transcription levels, and their triglyceride (TG) accumulation levels were reduced to $30 \%$ those of normally differentiated adipocytes. RT-PCR analysis also demonstrated a decrease in the expressions of some adipogenic genes including the master regulator of adipocyte gene transcription, PPAR $\gamma 2$, by EDHB-treated adipocytes, indicating the requirement for collagen during adipose conversion. The exogenous collagen types I, III, IV, V and VI were then individually supplied under EDHB conditions to determine whether or not they could make up for the lack of their own endogenous products. Of the five types of collagen, cells cultured on type $\mathrm{V}$ collagen were the only ones to improve the inhibitory effect of EDHB so as to recover up to $63.8 \%$ of TG content accompanied by the up-regulated expressions of PPAR $\gamma 2$ and adiponectin. These findings suggest that the extracellular signal from type $\mathrm{V}$ collagen is one of the major contributing factors in the differentiation pathway of porcine adipocytes.
\end{abstract}

Jpn. J. Swine Science, 58, $2: 53-64$

Key words : preadipocyte, type $\mathrm{V}$ collagen, extracellular matrix, adipocyte differentiation, pig

\section{Introduction}

In addition to its primary function in the storage and release of lipids, white adipose tissue (WAT) is increasingly realized as an active endocrine organ that secretes numerous proteins necessary for normal physiological homeostasis (GREGOIRE et al., 1998 ; WANG et al., 2008). An excessive adipose tissue mass leads to a dysregulation in the balance of those specific adipocyte-derived secretory proteins, thus increasing the risk of major diseases, including type 2 diabetes, cardiovascular disease, hypertension, dislipidemia, and even certain cancers (RAJALA and Scherer, 2003). A proteomic approach confirmed that extracellular matrix (ECM) and related proteins, particularly collagens,

連絡者：中島郁世（E-mail : ikuyon@affrc.go.jp TEL. 029-838-8686) 
were the major contributors to the secretion profiles of 3T3-L1 cells (WANG et al., 2004). Fullscale exploratory analysis of the human obese WAT transcriptomic signature highlighted the central place occupied by inflammatory and immune processes, and showed a strong interaction with ECM components (Henegar et al., 2008). Dynamic interplay among adipocytes, vascular endothelial cells and macrophages was visualized in living obese adipose tissue (Nishimura et al., 2007). It is now clear that growing adiposity is not merely a simple phenomenon of the hyperplasia and hypertrophy of adipocytes but is also associated with a substantial modulation of tissue structure involving angiogenesis, inflammation, and a continuous remodeling of ECM.

As preadipocytes lose their fibroblastic phenotype, the expression of fibrillar collagen types I, III, and fibronectin mRNAs declines, and instead, synthesis of type IV collagen, laminin, and entactin takes place (Aratani and Kitagawa, 1988 ; Weiner et al., 1989 ; Bortell et al., 1994). The a2(VI) mRNA content reaches its maximum in early differentiation after confluence, and maintains a relatively high level in lipid-laden adipocytes (DANI et al., 1989). Electron microscopy has revealed that fully differentiated spherical adipocytes are interconnected by abundant ECM rods and fibers of their own products (KuRI-HARCUCH et al., 1984). Immunological studies have shown that basement membrane proteins are not the only ECM components surrounding adipocytes; other types of collagen networks, such as I, III, V, and VI also assemble on the surface of adipocytes (NAKAJIMA et al., 1998 ; KuBo et al., 2000). Although it is widely accepted that extracellular macromolecules can regulate cell behavior, little is known about the biological significance of these changes in the ECM structure accompany adipogenesis.

Ethyl-3,4-dihydroxybenzoate (EDHB) serves as an effective competitive inhibitor of prolyl-4hydroxylase with which to search for the role of collagen in various cellular activities (NANDAN et al., 1990 ; IBRAhimi et al., 1992 ; Rocknik et al., 1998). The prolyl hydroxylase is a critical enzyme in- volved in the synthesis of procollagen, which converts certain proline residues to hydroxyproline within the rough endoplasmic reticulum. This posttranslational modification is essential for collagen to fold into a stable triple-helical conformation and for subsequent normal secretion into the extracellular space (KiviRikko et al., 1989). In this report, we conducted investigations using this chemical compound in a culture of an established porcine preadipose cell line (PSPA) (NAKAJIMA et al., 2003) to determine whether there is a need for collagens during adipocyte development. Our results indicate that EDHB markedly decreases the lipogenic action of the cells, but supplying exogenous type $\mathrm{V}$ collagen alone considerably recovers its inhibitory effect, a finding that suggests the important role of an extracellular signal from type $\mathrm{V}$ collagen for porcine adipocyte differentiation.

\section{Materials and Methods}

\section{Cell culture}

A stromal-vascular preadipocyte cell line (PSPA) isolated from the dorsal subcutaneous tissue of 85-day-old pig fetuses (NAKAJima et al., 2003) was used in this study. PSPA cells were maintained in the preadipose condition by cultivation in Dulbecco's modified Eagle's medium (DMEM, $1 \mathrm{~g} / \mathrm{L}$ glucose) (Gibco-BRL, Grand Island, NY, USA) supplemented with 10\% fetal bovine serum (FBS) (Gibco-BRL), $1000 \mathrm{U} / \mathrm{mL}$ penicillin, and $1 \mathrm{mg} / \mathrm{mL}$ streptomycin (Sanko Junyaku, Tokyo, Japan).

To produce mature adipocytes, PSPA cells were seeded at $2.1 \times 10^{4}$ cells $/ \mathrm{cm}^{2}$ and grown for 3 days to obtain confluence. After reaching confluence (day 0), adipose conversion was induced in highglucose $(4.5 \mathrm{~g} / \mathrm{L})$ DMEM containing 10\% FBS, $5 \mu \mathrm{g} / \mathrm{mL}$ insulin (Sigma Chemicals, St. Louis, MO, USA), $0.25 \mu \mathrm{M}$ dexamethasone (Sigma), $33 \mu \mathrm{M}$ biotin (Wako Pure Chemicals, Osaka, Japan), $17 \mu \mathrm{M}$ pantothenate (Wako), $5 \mathrm{mM}$ octanoate (Wako), and antibiotics. The medium was changed every other day, and the cells were allowed to differentiate for 10 more days. 
Table 1. Primer sequences and the accession numbers used in PCR experiments ${ }^{\mathrm{a}}$

\begin{tabular}{llll}
\hline \hline \multicolumn{1}{c}{ Gene } & & \multicolumn{1}{c}{ Primers } & Accession No. \\
\hline$a 2(\mathrm{I})$ & fw & TTGCTTGCAGTAACTTCGTGCCTAG & AB237775 \\
& rv & ACCAGCAGGTCCTTGGAAACCTTGA & \\
$a 1($ III) & fw & AAAGGATGGTCCAAGGGGTCCTACTGGT & BU946784 \\
& rv & TGCCACGTTCAACCTTTGACACCTT & \\
$a 1(\mathrm{IV})$ & fw & AATGACTACTCGTACTGGCTGTCCA & BC047305 \\
& rv & TTCTTGAACATCTCGCTCCGCTCTA & AU059561 \\
$a 2(\mathrm{~V})$ & fw & ACAGTGCCAGGATGTGCTTGAATGTG & AB097498 \\
& rv & ACCAGGAACACCTGGTTCTCCATCAA & \\
$a 2(\mathrm{VI})$ & fw & AGAAGTTCATCGACGACATGGAGGACGT & AB237779 \\
& rv & AAGCGCTGCGCCTTGTGGAAGTTCTGCT & \\
C/EBP $\alpha$ & fw & AAGTCGGTGGACAAGAACAGCAACGAGTA & Y11525 \\
& rv & AAGATGCCCCGCAGCGTGTCCAGTT & \\
adiponectin & fw & GGAGATACAGGTCTTACTGGTCCTA & AY135647 \\
& rv & CAGGAATGTTGCAGTGGAATTTGCCA & \\
\hline
\end{tabular}

${ }^{a}$ Abbreviations: fw, forward primer; rv, reverse primer; $\alpha 2(\mathrm{I})$, collagen type I alpha 2 chain; $\alpha 1(\mathrm{III})$, collagen type III alpha 1 chain; $\alpha 1(\mathrm{IV})$, collagen type IV alpha 1 chain; $a 2(\mathrm{~V})$, collagen type $\mathrm{V}$ alpha 2 chain; $\alpha 2(\mathrm{VI})$, collagen type VI alpha 2 chain; C/EBP, CCAAT enhancer-binding protein.

\section{Antibodies}

The following five rabbit antisera were used as primary antibodies: anti-bovine types I, III, IV, V and VI collagen antibodies (LSL Co., Tokyo, Japan). The specificity of all antibodies used in this study was verified by enzyme-linked immune sorbent assay (ELISA) and immunoblotting analysis. The secondary antibody used was a fluorescein-isothiocyanate (FITC) conjugated goat anti-rabbit immunoglobulin (Nordic Immunological Lab., Tilburg, Netherlands).

\section{Immunocytochemistry}

After culture on Lab Tek microslides (Nalge Nunc International K.K., Rochester, NY, USA), cells were fixed with $3.7 \%$ formaldehyde incubated at room temperature for $15 \mathrm{~min}$, rinsed, and reincubated in $1 \%$ bovine serum albumin in phosphate-buffered saline (PBS) for $30 \mathrm{~min}$ at $37^{\circ} \mathrm{C}$ to prevent nonspecific antibody binding. Cells were then reacted with the primary antibody overnight at $4^{\circ} \mathrm{C}$ and with the FITC-conjugated secondary antibody (1:500) for $30 \mathrm{~min}$ at $37^{\circ} \mathrm{C}$. Stained cell monolayers were observed using a Zeiss Axiophot microscope.

\section{Ethyl-3,4-dihydroxybenzoate (EDHB)}

EDHB (Sigma) was initially dissolved in absolute ethanol at a final concentration of $200 \mathrm{mM}$. The incubation with cells contained ethanol in a final concentration that depended on each EDHB dose added; the concentration of ethanol in the control cultures was adapted to the highest dose of EDHB in the experiments. In most cases, the final ethanol concentration of the controls was adjusted to $0.02 \%$. There were no significant differences in values between the controls that were incubated with ethanol and those that were not. All these procedures were performed according to SASAKI et al. (1987).

Extraction of RNA and reverse transcriptase-polymerase chain reaction ( $R T-P C R)$ analysis

Messenger RNAs were isolated from PSPA cells using the QuickPrep Micro mRNA Purification Kit (Amersham Biocsiences, Piscataway, NJ, USA) and then reverse transcribed using the First-Strand cDNA Synthesis Kit (Amersham). The synthesized 
cDNA was amplified with AmpliTaq Gold (Applied Biosystems Inc., Foster City, CA, USA) by PCR using paired forward and reverse primers (Table 1) with the ribosomal protein L7 (RPL7) as the internal control. We have shown previously that RPL7 is a suitable endogenous control for RT-PCR analysis when examining porcine adipose-related gene expression (Matsumoto et al., 2012 ; Nakajima et al., 2019). The nucleotide sequences of specific primers for peroxisome proliferator-activated receptors (PPAR) $\gamma 2$ and $\gamma 1$, adipocyte-specific fatty acid binding protein (aP2), lipoprotein lipase (LPL), hormone-sensitive lipase (HSL) and RPL7 have been described elsewhere (NAKAJIMA et al., 2003). PCR was conducted as follows: first for 9 min at $95^{\circ} \mathrm{C}$, followed by denaturation at $95^{\circ} \mathrm{C}$ for $30 \mathrm{sec}$, annealing at $55^{\circ} \mathrm{C}$ for $30 \mathrm{sec}$, and a $30-\mathrm{sec}$ extension at $72^{\circ} \mathrm{C}$ for $25-35$ cycles. A final elongation step was performed at $72^{\circ} \mathrm{C}$ for $7 \mathrm{~min}$. The PCR products were size-fractionated by $4 \%$ agarose gel electrophoresis and stained with ethidium bromide.

\section{Triglyceride assay}

Cultured cells on 6-well plates were washed with PBS, scraped off into $0.4 \mathrm{~mL}$ of $25 \mathrm{mM}$ Tris$\mathrm{HCl}(\mathrm{pH}$ 7.5) containing $1 \mathrm{mM}$ EDTA, and then homogenized. Triglyceride (TG) in the cell lysate was extracted with the same volume of chloroformmethanol $(2: 1, \mathrm{v} / \mathrm{v})$ and quantified enzymatically using a Triglyceride G Test Kit (Wako).

\section{Preparation of collagen substrates and coating of dishes}

Cells were plated on dishes coated with various compounds as follows: Collagen I (calf skin), III and V (bovine placenta) were obtained from Koken Co. (Tokyo, Japan), and collagen IV (bovine lens capsule) was purchased from Wako. The method of Kuo et al. (1995) was followed to obtain filaments of type VI collagen from the bovine placenta. These collagen solutions were diluted with sterile physiological saline to a final concentration of $20 \mu \mathrm{g} / \mathrm{mL}$. The 6 -well plates were covered with $20 \mu \mathrm{g}$ each per well and incubated overnight at $4^{\circ} \mathrm{C}$. ECM dilutions were removed before use as described previously (NAKAJIMA et al., 2002).

\section{Statistical analysis}

Data were analyzed for statistical significance using Student's $t$-test.

\section{Results}

Collagen matrix development during adipocyte differentiation

The stromal vascular PSPA cell line derived from porcine subcutaneous tissue showed a typical fibroblastic morphology at the proliferation stage (Fig. 1F). These preadipocytes were found to be capable of producing types I, III, IV, V and VI collagens as detected by indirect immunofluorescence staining (Fig. 1A-1E). When confluent cultures were stimulated with differentiation medium, by day 10 the PSPA cells exhibited numerous and large cytoplasmic lipids (Fig. 2G). Following fluorescence microscopy, all five collagens were positively stained at the adipose state with some showing a prominent fibrillar network (Fig. 2H, 2K, 2L) and others round in shape (Fig. 2I, 2J), while extracellular collagens were hardly (Fig. 2C, 2D) or only slightly (Fig. 2B, 2E, 2F) detected from the cell surface of confluent preadipocytes (Fig. 2A).

Effect of inhibiting collagen matrix assembly by $E D H B$ on adipocyte differentiation

In order to study the role of collagen during adipocyte differentiation, EDHB was used as a specific inhibitor for collagen synthesis. By the addition of EDHB to the adipogenic medium, the localization pattern of the fiber network formation of collagens was drastically reduced until undetectable or extremely fragmented (Fig. 2N-2R), which was very similar to those of preadipocyte state. Although only sparse extracellular immunoreactivity was evident in EDHB-treated adipocytes, the steady state level of every collagen $a$-chain mRNA was equally expressed in both cultures, either including the compound or not (Fig. 3), according to the known inhibitory effect of EDHB which influences the post-transcriptional maturation of 

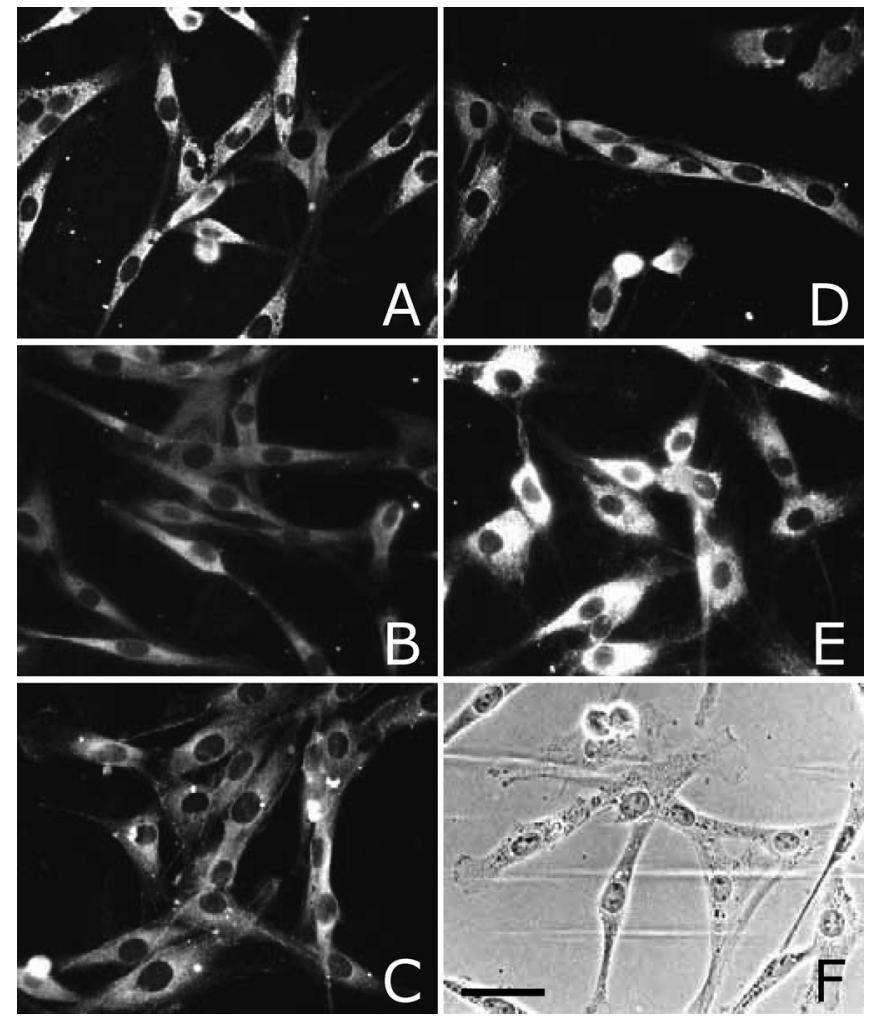

Fig. 1. Production of various types of collagen by growing preadipocytes. PSPA cells were cultured for 2 days in growth medium and then subjected to indirect immunofluorescence staining. Primary antibodies were as follows: antiserum against types I (A), III (B), IV (C), V (D) and VI (E) collagen individually. The phase-contrast image (F) shows the fibroblast-like morphology of PSPA cells. Scale bar in (F) is $50 \mu \mathrm{m}$ and applies to all panels.

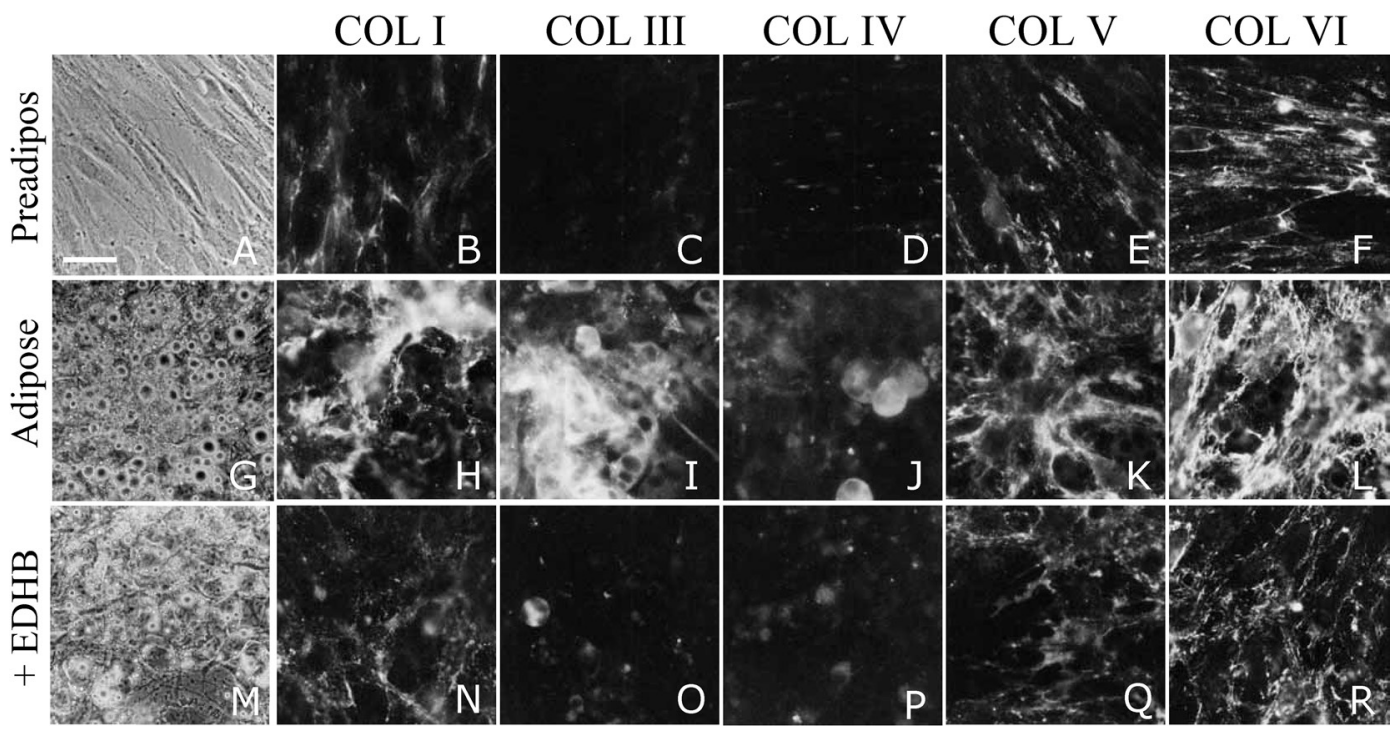

Fig. 2. Interrupted formation of collagen fiber network in adipocytes by EDHB. Confluent PSPA cells were shifted to either an adipogenic medium in the absence (Adipose; G-L) or presence (+EDHB; M-R) of $40 \mu \mathrm{M}$ EDHB or merely in a non-adipogenic growth medium (Preadipose: A-F) to maintain the cell in a preadipose state. After a 10-day culture, each type of collagens was detected by the indirect immunofluorescence method: collagens I (COL I; B, H, N), III (COL III; C, I, O), IV (COL IV; D, J, P), V (COL IV; E, K, Q) and VI (COL VI; F, L, R). Scale bar in (A) is $50 \mu \mathrm{m}$ and applies to all panels. 


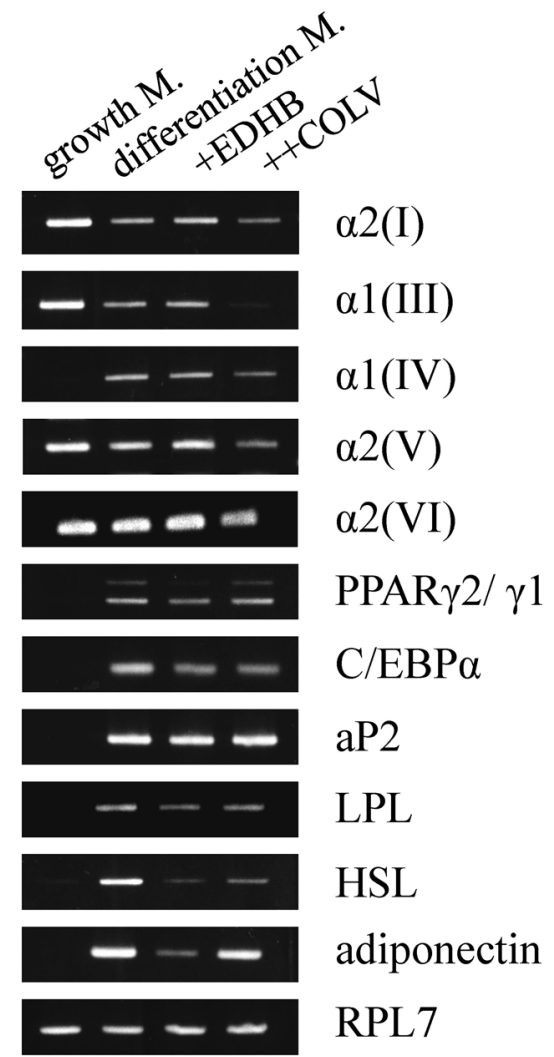

Fig. 3. Collagen synthesis and adipocyte-specific gene expressions under various conditions of PSPA cells. At 10 days after confluence, mRNA was extracted from the cells maintained in growth medium (growth M.), differentiation medium (differentiation M.), differentiation medium with $40 \mu \mathrm{M}$ EDHB $(+\mathrm{EDHB})$, and in type $\mathrm{V}$ collagen-coated dishes in the presence of EDHB $(++\mathrm{COL}$ $\mathrm{V})$. The levels of $\alpha 2(\mathrm{I}), \alpha 1(\mathrm{III}), \alpha 1(\mathrm{IV}), \alpha 2(\mathrm{~V})$, $\alpha 2(\mathrm{VI}), \mathrm{PPAR} \gamma 2, \gamma 1, \mathrm{C} / \mathrm{EBP} \alpha$, aP2, LPL, HSL, adiponectin, and RPL7 expression were analyzed by RT-PCR. Results are representative of at least two independent experiments.

collagen synthesis (SASAKi et al., 1987). On the other hand, abundant collagen synthesis was also observed in undifferentiated preadipocytes with a somewhat stronger signal than adipocytes, indicating that the assembling of collagen matrices on cell surfaces could only depend on adipose conversion. However, type IV collagen, one of the major basement membrane components, the production of which links with adipocyte differentiation, was not detected in a preadipose state.

We next tested whether these extracellular ma-

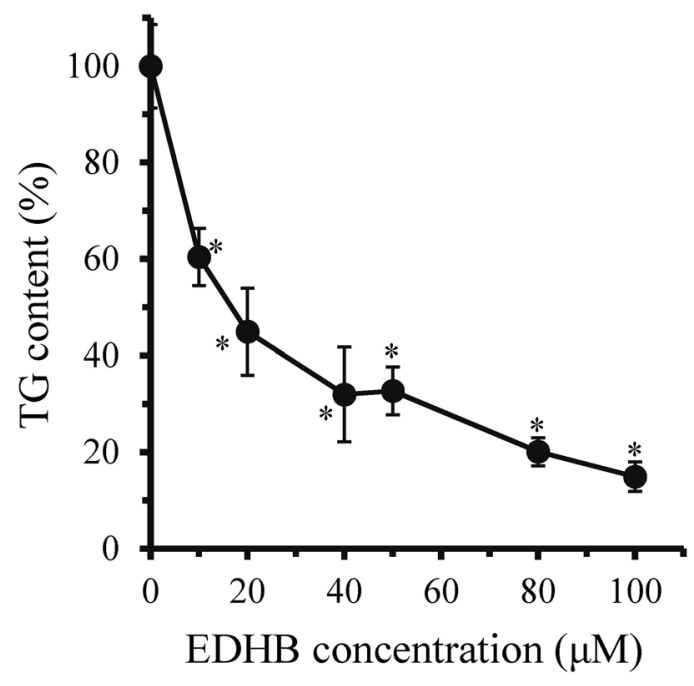

Fig. 4. Reduction of TG accumulation in adipocytes by EDHB. Confluent PSPA cells were stimulated with an adipogenic medium in the presence of various concentrations of EDHB. TG content of normal adipocytes was indicated to be $100 \%$. Results are representative of at least three independent experiments and are expressed as mean $\pm \mathrm{SD}$ of triplicate dishes. Statistical analysis showed significant decreases of TG accumulation when compared with control adipocytes which were treated without $\operatorname{EDHB}\left({ }^{*} \mathrm{P}<0.005\right)$.

trix developments of collagens were necessary for adipogenesis itself. The addition of various concentration of EDHB to the culture medium reduced the amount of TG accumulation of PSPA cells in a dose-dependent manner (Fig. 4). A dose of $40 \mu \mathrm{M}$ EDHB was used in this study, since the inhibitory effect was found to reach a plateau at this concentration, and the level of TG content declined by $70 \%(\mathrm{P}<0.005)$ without showing any abnormalities, but smaller lipid droplets than those of control adipocytes (Fig. 2M). EDHB decreased not only the TG content, the final products of adipocytes, but also down-regulated the expression of genes greatly involved in lipogenesis which encode some transcription factors (PPAR $\gamma 2, \mathrm{C} / \mathrm{EBP} a$ ), enzymes (LPL, HSL) and adipokine (adiponectin) (Fig. 3).

Exogenous type $V$ collagen recovers differentiation of EDHB-treated adipocytes

It is recognized that ECM, in addition to provid- 
A

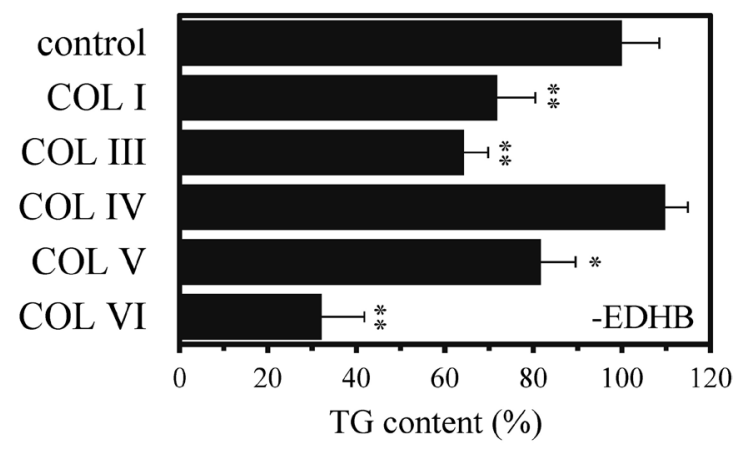

B

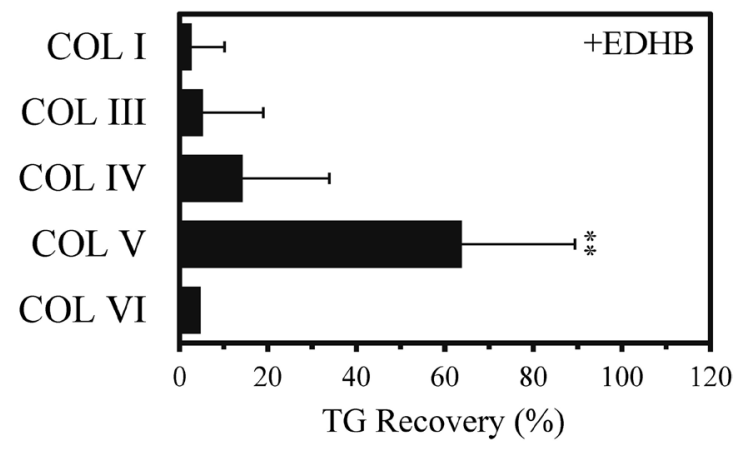

Fig. 5. Effect of exogenous collagen substrata on adipocyte differentiation. PSPA cells were cultured on plastic or collagen-coated (type I, III-VI) dishes, and stimulated with differentiation medium (A) or in the presence of $40 \mu \mathrm{M} \operatorname{EDHB}$ (B) at confluence. TG content was determined after 10 more days of culture. (A) The percentage of TG content was obtained from the value of collagen-coated adipocytes over the value of non-coated adipocytes (100\%: $4.76 \pm$ $0.05 \mu \mathrm{g} / 10^{4}$ cells). The value of preadipocytes was taken as $0 \%\left(0.09 \pm 0.02 \mu \mathrm{g} / 10^{4}\right.$ cells $)$. Results are means of two independent experiments performed in duplicate wells. (B) The percentage of TG content was obtained from the value of EDHB-treated adipocytes over the value of non-treated and noncoated normal adipocytes (100\%: $4.63 \pm$ $0.52 \mu \mathrm{g} / 10^{4}$ cells). The value of EDHB-treated adipocytes without collagen supplements was taken as $0 \%\left(1.81 \pm 0.05 \mu \mathrm{g} / 10^{4}\right.$ cells $)$. Results are means of two independent experiments performed in duplicate wells. Statistical analysis showed significant differences in TG accumulation when compared with control adipocytes cultured without any collagen supplements. ${ }^{*} \mathrm{P}<0.05,{ }^{* *} \mathrm{P}<0.01$. ing mechanical support and adhesion for tissues, plays an active and complex role in regulating the growth and differentiation of the cells with which it comes in contact. The results in Fig. 5A demonstrate that cells cultured on dishes coated with collagen types I, III, V and VI decreased the level of TG content $(\mathrm{P}<0.05)$, but that cells plated on collagen type IV developed to the same extent as the control on plastic. In addition to normally differentiated adipocytes, it was of interest to determine whether the significant inhibition in the level of fat accumulation brought on by the presence of EDHB could be influenced by specific exogenous collagens. We therefore cultured the cells on various types of collagen to complement the lipogenic action of EDHB adipocytes. None of the extrinsic proteins was able to significantly improve the reduced amount of TG caused by the collagen inhibitor, except only when the cells were cultured on dishes coated with type V collagen (Fig. 5B). Type $\mathrm{V}$ collagen alone dramatically increased the TG content at a recovery rate of $63.8 \%(\mathrm{P}<0.01)$. The RT-PCR studies presented in Fig. 3 showed that the expression of the adipose-specific member genes PPAR $\gamma 2$ and adiponectin was up-regulated in EDHB adipocytes supported with collagen $\mathrm{V}$, while they still remained at lower levels of $\mathrm{C} / \mathrm{EBP} \alpha$ and HSL.

\section{Discussion}

EDHB, which is a structural analog of ascorbate, serves as a competitive inhibitor of prolyl hydroxylase (KivirikKo et al., 1989). It has been shown that the compound markedly impairs the secretion of functional collagen by post-transcriptional levels in human fibroblasts without affecting their viability, proliferative capacity, or plating efficacy (SASAKI et al., 1987). Our current results also show that EDHB acts as a post-transcriptional inhibitor, since there was a remarkable disappearance in the formation of a collagen fiber network from adipocyte cell surfaces despite their steady-state level of mRNA expressions. By using this ideal inhibitor, we demonstrated that extracellular type V collagen was necessary for porcine adipocyte develop- 
ment.

The ECMs, an important component of the cellular environment, are mainly produced locally by cells of a fibroblast family in the matrix. Previous studies on both mouse and bovine preadipocytes have shown their capability of simultaneously synthesizing various kinds of ECM components including collagens, laminin and fibronectin (WEINER et al., 1989 ; NAKAjIma et al., 1998 ; KuBo et al., 2000), as well as fibroblasts (OLsEn et al., 1989). Similarly, our immunocytochemical stainings showed that PSPA cells, a porcine subcutaneous preadipose cell line, were able to produce types I, III, IV, V and VI collagens (Fig. 1), thus indicating that the adipocyte precursor cells with a fibroblastic appearance have a strong propensity for collagen synthesis in general.

Besides dramatic increases in the proteins directly related to fat metabolism, alterations occur as well in the cell shape and extracellular environment during adipocyte differentiation. Electron microscopy reveals that every adipocyte is supported by a basement membrane and is interconnected with an abundance of fibers and rods which cannot be seen in fibroblast-like preadipocytes (NApolitano, 1963 ; Kuri-HarCuch et al., 1984). These surroundings of adipocytes are a complex of ECM macromolecules comprised of numbers of collagens, structural glycoproteins and proteoglycans (CAlvo et al., 1991 ; NAKAjima et al., 1998 ; KuBo et al., 2000). A proteomic approach using two-dimensional gel electrophoresis and mass spectrometry has revealed the secretion profiles of 3T3-L1 adipocytes as a dynamic environment of actively remodeling ECM (WANG et al., 2004). We have demonstrated that with porcine adipocytes, intensive fibrillar networks of collagens types I, III, IV, V and VI are likely to form fat cell clusters (Fig. 2H-2L). Moreover, these in vitro studies are complemented by in vivo studies showing that extracellular space in adipose tissue, the loose connective tissue sheath surrounding adipocytes, deposits a variety of ECM composed of collagens and other proteins as examined by immunohistochemistry (NAKajima et al., 1998 ; Pierleoni et al.,
1998). However, there is often some conflict with the data raised by either protein or mRNA analysis, especially regarding the effect on fibrillar collagens during adipogenesis; it is generally accepted that preadipocytes are predominant in expressing procollagen mRNAs compared to adipocytes, and that their transcription level decreases upon adipose conversion (WEINER et al., 1989 ; Bortell et al., 1994 ; URs et al., 2004). We may have reconciled this contradictory result in our present study. Indeed, high levels of types I, III, V and VI collagen mRNA transcripts rather than adipocytes have been identified as being expressed by PSPA preadipocytes (Fig. 3). Despite this fact, it is of interest to note that collagen protein depositions observed on the cell surface of adipocytes were hardly detected from these undifferentiated cells (Fig. 2B$2 F)$, i.e., preadipocytes mainly produce secretory collagens in culture medium just as fibroblasts do (Alitalo et al., 1982), but following the induction to adipocyte differentiation, the cells are forced to assemble a collagen matrix as well as a basement membrane construction via some changes in contacts between ECM proteins and their receptors such as integrins (RodRíguez-FERnÁNdEZ and BENZE'EV, 1989 ; LiU et al., 2005).

Why adipose cells are interconnected with collagen fibrils remains unclear. However, the requirement of collagen seems essential across all animal species to accomplish the terminal differentiation program of adipocytes. Impairing the ECM network by the addition of EDHB reduces the level of glycerophosphate dehydrogenase activity in mouse adipocytes (IBRAHIMI et al., 1992), and the amount of TG accumulation in bovine (NAKAJIMA et al., 2002) and porcine adipocytes (Fig. 4). Its inhibitory effect observed on PSPA cells was not only limited to the later stages of the lipogenic pathway but was already evident from the expression of one of the key transcription factors, PPAR $\gamma 2$ (Fig. 3), strongly indicating the important role of collagen at the early stage of adipose development, which was quite similar with the previous works (IBRAHIMI et al., 1992 ; NAKAJIMA et al., 2002).

As generally understood, collagens are exclu- 
sively localized in extracellular matrices, where they serve diversified functions involving developmental programs and physiological actions in many cell types through a process known as outside-in signaling. Without exception, ECM proteins influence adipocyte differentiation which is often negatively affected by fibronectin and positively by the basement membrane relatives (Spiegelman and Ginty, 1983 ; Rodríguez-Fernández and Ben-Ze'ev, 1989 ; Hausman et al., 1996 ; YoneMITSU et al., 1998). We additionally showed that subjecting preadipocytes to types I, III, IV, V and VI collagen, respectively, ended up exerting an inhibitory effect on adipose conversion by fibrillar collagens but not by type IV collagen (Fig. 5). On the other hand, it become evident that adipocytes need to make contact with type $\mathrm{V}$ collagen during the differentiation process, since type $\mathrm{V}$ was the only collagen to recover the down-regulated TG content and those of adipocyte-specific gene expressions caused by EDHB (Fig. 5). Our former study with bovine intramuscular adipocytes cultured in the presence of EDHB has shown that an improvement in TG content by collagen coating was obtained not so much from collagen type $\mathrm{V}$ as from type VI, and that their recovery rates were quite low compared to those of PSPA cells (NAKAJIMA et al., 2002). This may depend on the species or adipose tissue depots because preadipocytes from different sources often vary in their responsiveness to distinct agents (Gregoire et al., 1998). As it turned out, the intracellular lipid accumulation of the EDHB-treated adipocytes with type $\mathrm{V}$ collagen-coated was still insufficient compared to the normal adipocytes, and the gene expressions of several adipocyte markers were unimproved after all. Hence, to obtain a complete differentiation program, in addition to type $\mathrm{V}$ collagen, some other factors seem needed.

There is no information concerning type V collagen with adipogenesis. Type $\mathrm{V}$ collagen is a quantitatively minor fibrillar collagen with a broad tissue distribution that regulates collagen type I fibrillogenesis. Its molecular characteristic is also known to be quite multi-adhesive, including do- mains for cell adhesion, binding growth factors, and interactions with other ECM components as well (Fichard et al., 1994). A retrievable effect by exogenous type $\mathrm{V}$ collagen similar to that in our present study has recently been reported in other systems, such as fibroblasts derived from classical Ehlers-Danlos syndrome patients with type V collagen deficiency during abnormal wound healing (VigLio et al., 2008). Furthermore, several papers have reported that type $\mathrm{V}$ collagen can alter cellular actions through outside-in ECM signaling pathways (Luparello and Sirchia, 2005 ; Murasawa et al., 2008). We have proposed an active and additional new role of type $\mathrm{V}$ collagen from extracellular signals in the regulation of adipocyte development, particularly in pigs.

\section{Acknowledgments}

This work was supported partly by a grant from the Animal genome research project of the Ministry of Agriculture, Forestry and Fisheries, Japan (Functional analysis of rice and animal genome).

\section{References}

Alitalo, K., E. Kuismanen, R. Myllylä, U. Kisstala, S. Asko-Seljavaara and A. Vaheri : 1982, Extracellular matrix proteins of human epidermal keratinocytes and feeder 3T3 cells, J. Cell Biol., 94, 497-505.

Aratani, Y. and Y. Kitagawa : 1988, Enhanced synthesis and secretion of type IV collagen and entactin during adipose conversion of 3T3-L1 cells and production of unorthodox laminin complex, J. Biol. Chem., 263, 16163-16169.

Bortell, R., T.A. Owen, R. Ignotz, G.S. Stein and J.L. SteIN : 1994, TGF $\beta_{1}$ prevents the down-regulation of type I procollagen, fibronectin, and TGF $\beta_{1}$ gene expression associated with 3T3-L1 preadipocyte differentiation, J. Cell Biochem., 54, 256-263.

Calvo, J.C., D. Rodbard, A. Katki, S. Chernick and M. Yanagishita : 1991, Differentiation of 3T3-L1 preadipocytes with 3-isobutyl-1-methylxanthine and dexamethasone stimulates cell-associated and soluble chondroitin 4-sulfate proteoglycans, J. Biol. Chem., 266, 11237-11244.

Dani, C., A. Doglio, E.-Z. Amri, S. Bardon, P. Fort, 
B. Bertrand, P. Grimaldi and G. Ailhaud : 1989, Cloning and regulation of a mRNA specifically expressed in the preadipose state, J. Biol. Chem., 264, 10119-10125.

Fichard, A., J.-P. Kleman and F. Ruggiero : 1994, Another look at collagen $\mathrm{V}$ and XI molecules, Matrix Biol., 14, 515-531.

Gregoire, F.M., C.M. Smas and H.S. Sul : 1998, Understanding adipocyte differentiation, Physiol. Rev., 78, 783-809.

Hausman, G.J., J.T. Wright and R.L. Richardson : 1996, The influence of extracellular matrix substrata on preadipocyte development in serumfree cultures of stromal-vascular cells, J. Anim. Sci., 74, 2117-2128.

Henegar, C., J. Tordjman, V. Achard, D. Lacasa, I. Cremer, M. Guerre-Millo, C. Poitou, A. Basdevant, V. Stich, N. Viguerie, D. Langin, P. Bedossa, J.-D. Zucker and K. Clement : 2008, Adipose tissue transcriptomic signature highlights the pathological relevance of extracellular matrix in human obesity, Genome. Biol. 9, R14.

Ibrahimi, A., F. Bonino, S. Bardon, G. Ailhaud and C. DANI : 1992, Essential role of collagens for terminal differentiation of preadipocytes, Biochem. Biophys. Res. Commun., 187, 1314-1322.

Kivirikko, K.I., R. Myllylä and T. Pihlajaniemi : 1989, Protein hydroxylation: prolyl 4-hydroxylase, an enzyme with four cosubstrates and a multifunctional subunit, FASEB J., 3, 1609-1617.

Kubo, Y., S. Kaidzu, I. Nakajima, K. Takenouchi and F. NAKAMURA : 2000, Organization of extracellular matrix components during differentiation of adipocytes in long-term culture, In Vitro Cell Dev. Biol. Anim., 36, 38-44.

Kuo, H.-J., D.R. KeEne and R.W. Glanville : 1995, The macromolecular structure of type-VI collagen: formation and stability of filaments, Eur. J. Biochem., 232, 364-372.

Kuri-Harcuch, W., C. Argüello and M. MarschMorEno : 1984, Extracellular matrix production by mouse 3T3-F442A cells during adipose differentiation in culture, Differentiation, 28, 173-178.

Liu, J., S.M. DeYoung, M. Zhang, M. Zhang, A. Cheng and A.R. SAltiel : 2005, Changes in integrin expression during adipocyte differentiation, Cell Metab., 2, 165-177.

Luparello, C. and R. Sirchia : 2005, Type V collagen regulates the expression of apoptotic and stress response genes by breast cancer cells, J. Cell Physiol., 202, 411-421.
Matsumoto, T., I. Nakajima, T. Eguchi-Ogawa, Y. Nagamura, N. Hamashima and H. Uenishi : 2012, Changes in gene expression in a porcine preadipocyte cell line during differentiation, Anim. Genet., 43, 535-544.

Murasawa, Y., T. Hayashi and P.-C. Wang: 2008, The role of type $\mathrm{V}$ collagen fibril as an ECM that induces the motility of glomerular endothelial cells, Exp. Cell Res., 214, 3638-3653.

Nakajima, I., T. Yamaguchi, K. Ozutsumi and H. Aso : 1998, Adipose tissue extracellular matrix: newly organized by adipocytes during differentiation, Differentiation, 63, 193-200.

Nakajima, I., S. Muroya, R. Tanabe and K. Chikuni : 2002, Positive effect of collagen V and VI on triglyceride accumulation during differentiation in cultures of bovine intramuscular adipocytes, Differentiation, 70, 84-91.

Nakajima, I., S. Muroya and K. Chikuni : 2003, Growth arrest by octanoate is required for porcine preadipocyte differentiation, Biochem. Biophys. Res. Commun., 309, 702-708.

Nakajima, I., M. Kojima, M. Oe, K. Ojima, S. Muroya and K. Chikuni : 2019, Comparing pig breeds with genetically low and high backfat thickness: differences in expression of adiponectin, its receptor, and blood metabolites, Domest. Anim. Endocrinol., 68, 54-63.

Nandan, D., E.P. Clarke, E.H. Ball and B.D. Sanwal : 1990, Ethyl-3,4-dihydroxybenzoate inhibits myoblast differentiation: evidence for an essential role of collagen, J. Cell Biol., 110, 1673-1679.

Napolitano, L. : 1963, The differentiation of white adipose cells: an electron microscope study, J. Cell Biol., 18, 663-679.

Nishimura, S., I. Manabe, M. Nagasaki, Y. Hosoya, H. Yamashita, H. Fujita, M. Ohsugi, K. Tobe, T. Kadowaki, R. Nagai, and S. Sugiura : 2007, Adipogenesis in obesity requires close interplay between differentiating adipocytes, stromal cells, and blood vessels, Diabetes, 56, 1517-1526.

Olsen, D.R., J. Peltonen, S. JaAkkola, M.-L. Chu and J. Uitтo : 1989, Collagen gene expression by cultured human skin fibroblasts, J. Clin. Invest., 83, 791-795.

Pierleoni, C., F. Verdenelli, M. Castellucci and S. CinTI : 1998, Fibronectins and basal lamina molecules expression in human subcutaneous white adipose tissue, Eur. J. Histochem., 42, 183-188.

Rajala, M.W. and P.E. Scherer : 2003, Minireview: the adipocyte - at the crossroads of energy 
homeostasis, inflammation, and atherosclerosis. Endocrinology, 144, 3765-3773.

Rocnik, E.F., B.M.C. Chan and J.G. Pickering : 1998, Evidence for a role of collagen synthesis in arterial smooth muscle cell migration, J. Clin. Invest., 101, 1889-1898.

Rodríguez-Fernández, J.L. and A. Ben-Ze'ev : 1989, Regulation of fibronectin, integrin and cytoskeleton expression in differentiating adipocytes: inhibition by extracellular matrix and polylysine, Differentiation, 42, 65-74.

Sasaki, T., K. Majamaa and J. Uitto : 1987, Reduction of collagen production in keloid fibroblast cultures by ethyl-3,4-dihydroxybenzoate, J. Biol. Chem., 262, 9397-9403.

Spiegelman, B.M. and C.A. Ginty : 1983, Fibronectin modulation of cell shape and lipogenic gene expression in 3T3-adipocytes, Cell, 35, 657-666.

Urs, S., C. Smith, B. Campbell, A.M. Saxton, J. Taylor, B. Zhang, J. Snoddy, B.J. Voy and N. Moustaid-Moussa : 2004, Gene expression profiling in human preadipocytes and adipocytes by microarray analysis, J. Nutr., 134, 762-770.

Viglio, S., N. Zoppi, A. Sangalli, A. Gallanti, S.
Barlati, M. Mottes, M. Colombi and M. Valli : 2008, Wound repair capability in EDS fibroblasts can be retrieved by exogenous type $\mathrm{V}$ collagen, ScientificWorldJournal, 8, 956-958.

Wang, P., E. Mariman, J. Keijer, F. Boumman, J.-P. Noben, J. Robben and J. Renes : 2004, Profiling of the secreted proteins during 3T3-L1 adipocyte differentiation leads to the identification of novel adipokines, Cell Mol. Life Sci., 61, 2405-2417.

Wang, P., E. Mariman, J. Renes and J. Keijer : 2008, The secretory function of adipocytes in the physiology of white adipose tissue, J. Cell Physiol., 216, 3-13.

Weiner, F.R., A. Shah, P.J. Smith and C.S. Rubin : 1989, Regulation of collagen gene expression in 3T3-L1 cells. Effects of adipocyte differentiation and tumor necrosis factor $\alpha$, Biochemistry, 28, 4049-4099.

Yonemitsu, N., F. Bittinger, T. Gerheld, H. Sugihara, C. Mittermayer and C.J. Kirkpatrick : 1998, Influence of extracellular matrix on the lipogenesis of cultured white fat cells, Acta Histochem. Cytochem., 31, 9-15. 


\title{
ブタの脂肪細胞分化におけるV 型コラーゲンの重要性
}

\author{
中島郁世 ${ }^{1} \cdot$ 中村富美男 $^{2} \cdot$ 千国幸一 ${ }^{1}$ \\ ${ }^{1}$ 国立研究開発法人農業・食品産業技術総合研究機構 畜産研究部門, 茨城県つくば市, 305-0901 \\ 2 国立大学法人北海道大学大学院農学研究科, 北海道札幌市, 060-8589
}

(2020 年 9 月 8 日受付, 2020 年 12 月 16 日受理)

要 約 脂肪組織は、結合組織が変化したものである。これまでの研究から, 脂肪細胞分化 には結合組織の主要な成分であるコラーゲンが必要であることが知られている。本研究では, ブタの脂肪細胞分化に拉いてもコラーゲンが必要であるのかどうかを明らかにするため, ブタ 皮下組織由来脂肪前駆細胞株（PSPA 細胞）に対するコラーゲン合成阻害剂（EDHB）の影響 を検討した。免疫染色の結果、線維芽細胞様の PSPA 前駆細胞は I, III, IV, V およびVI 型 コラーゲンを産生し, 脂肪細胞への分化によりその細胞表面上に前駆細胞にはないコラーゲン ネットワークを構築することが観察された。遺伝子発現解析の結果, 前駆細胞でも十分量のコ ラーゲン mRNA が合成されているにもかかわらず細胞表面上に形成されるコラーゲンネット ワークは脂肪細胞でのみ認められる現象であることが明らかになった。次に分化培地に EDHB $40 \mu \mathrm{M}$ を添加し PSPA 細胞自身のコラーゲン生合成を抑制すると, 脂肪細胞の表面上に構築 されるべきコラーゲンネットワークが消失しただけでなく細胞内の脂肪蓄積量は $1 / 3$ にまで減 少し, 加えて脂肪細胞特異的な遺伝子の発現量の低下が見られたことから, 脂肪細胞分化にコ ラーゲンが必要であることが明らかになった。さらにEDHB 添加による PSPA 細胞のコラー ゲン自己産生能を抑制した状況下で細胞外からコラーゲンを補填した場合, PSPA 細胞の脂肪 蓄積量が回復するかを調べた。その結果，I， III，IV，V お おびVI 型コラーゲンのうちV 型 コラーゲンでのみ脂肪蓄積量が $63.8 \%$ ほど回復し, 転写因子 PPAR $\gamma 2$ やアディポネクチン遺 伝子の発現量も増加した。以上のことから, ブタの脂肪細胞分化には細胞外からの V 型コラー ゲンのシグナルが重要な役割を担っている可能性が高いことが示唆された。

キーワード : 脂肪前駆細胞, $\mathrm{V}$ 型コラーゲン, 細胞外マトリックス, 脂肪細胞分化, ブタ 